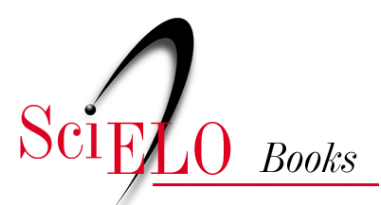

\title{
8. A Crença na Autointoxicação por Estase Intestinal e sua História
}

\author{
Joffre Marcondes de Rezende
}

\section{SciELO Books / SciELO Livros / SciELO Libros}

REZENDE, J. M. A Crença na Autointoxicação por Estase Intestinal e sua História. In: $\grave{A}$ sombra do plátano: crônicas de história da medicina [online]. São Paulo: Editora Unifesp, 2009, pp. 83-96. História da Medicina series, vol. 2. ISBN 978-85-61673-63-5. https://doi.org/10.7476/9788561673635.0009.

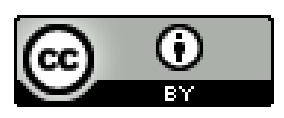

All the contents of this work, except where otherwise noted, is licensed under a Creative Commons Attribution 4.0 International license.

Todo o conteúdo deste trabalho, exceto quando houver ressalva, é publicado sob a licença Creative Commons Atribição 4.0.

Todo el contenido de esta obra, excepto donde se indique lo contrario, está bajo licencia de la licencia Creative Commons Reconocimento 4.0. 
A Crença na Autointoxicação por Estase Intestinal e sua História*

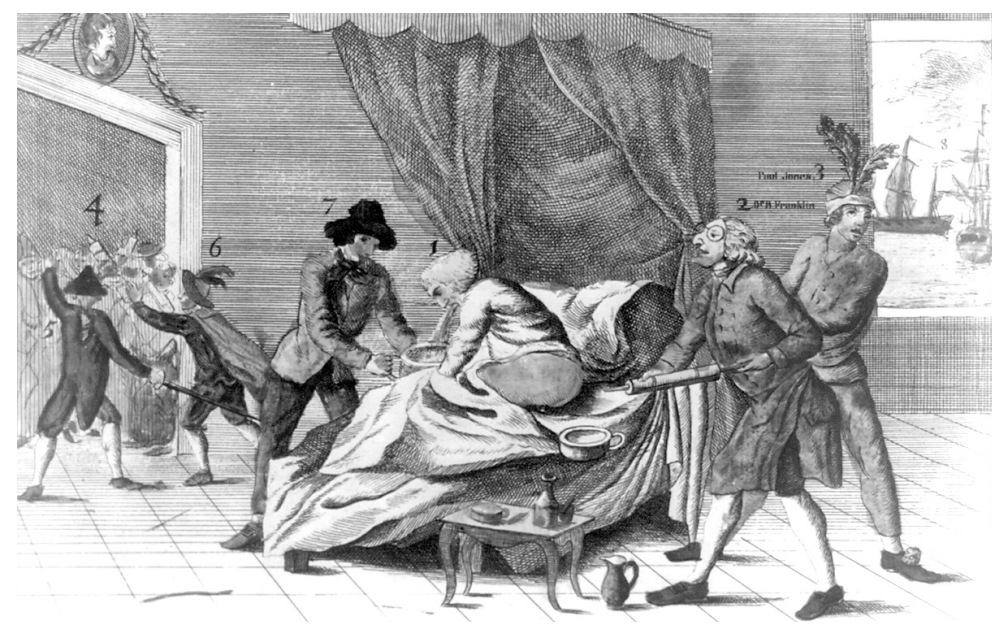

Seringa usada para clister, século XVIII.

crença de que as fezes contêm substâncias tóxicas para o organismo
e de que estas podem ser absorvidas e causar doenças remonta aos antigos egípcios. No papiro Anonimo Londinense encontra-se o seguinte trecho: "qualquer alimento ingerido que não é absorvido pelo organismo e que permanece nos órgãos, com o calor do corpo gera resíduos que sofrem putrefação e causam enfermidades".

Segundo Tamayo, na transição da medicina mágico-sacerdotal para a medicina empírico-racional, esta é a primeira interpretação da enfermidade como um fenômeno natural (Tamayo, ı988, p. 75).

$\mathrm{Na}$ decifração dos hieróglifos, encontrou-se repetidamente a sequência de letras $w h d w$ que foi traduzida em alfabeto latino por oukhedou. Acreditou-se durante algum tempo que se tratasse de alguma doença.

Segundo Steuer, o verdadeiro sentido do termo é de um princípio tóxico contido nas fezes, o qual, quando absorvido, coagula o sangue, produzindo

* Publicado na revista Brasília Médica, 40, pp. 33-42, 2003. 
abscessos ou corrupção sistêmica do organismo. A decomposição do cadáver, que se inicia pelo intestino, e a supuração patológica, são consideradas manifestações equivalentes da putrefação orgânica causada por este princípio tóxico (Tamayo, op. cit., p. 73).

Os médicos egípcios atribuíam ao oukhedou muitas enfermidades e explicavam inclusive o envelhecimento como consequência de sua absorção contínua pelo organismo. Como tratamento e profilaxia das doenças prescreviam com frequência purgativos, eméticos e clisteres, visando à retirada deste princípio tóxico do organismo. A sangria também era utilizada em alguns casos com a mesma finalidade.

Heródoto (II.77) deixou-nos, a propósito dos egípcios, o seguinte depoimento: "Em sua maneira de viver, têm o costume de purgar-se todos os meses do ano, por três dias consecutivos, procurando viver com saúde a custa de eméticos e clisteres, persuadidos de que todos os achaques e enfermidades do homem procedem dos alimentos" (Heródoto, I98 I, p. 82).

No papiro de Ebers há pelo menos doze receitas de purgativos, destinados a "liberar o ventre e expelir todas as coisas más que estão no corpo do doente" (Saint-Hieble, s.d., pp. I I-I 2).

Sobre o clister havia a lenda de que a íbis, ave sagrada dos egípcios, praticava em si mesma a limpeza da cloaca enchendo o bico de água e introduzindo-o através do ânus (Leca, I97 I; Dumesnil, I935, p. I66). Skinner lembra que o deus Thoth, da mitologia egípcia, era representado com a cabeça da íbis e poderia ser ele, e não a ave, que ensinara o uso do clister para limpeza do reto (Skinner, I96I, pp. I60-I6I).

Estas ideias e conceitos etiopatogênicos dos egípcios trasladaram-se para a medicina grega, de início para a escola de Cnidos e, a seguir, para a escola hipocrática de Cós. Eurifos de Cnidos substituiu o termo hieroglífico oukhedou pela palavra grega peritomata, cujo sentido é o de "resíduos" (Tamayo, op. cit., p. 75).

A crença nos efeitos benéficos da lavagem intestinal no tratamento das doenças e como medida higiênica visando preservar a saúde parece ser intuitiva e comum a várias culturas, que se desenvolveram isoladamente, sem comunicação entre si.

$\mathrm{Na}$ civilização asteca, por exemplo, as lavagens eram muito utilizadas, sendo designadas por notepamaca. Os araucanos, na América do Sul, usa- 
vam para a administração de enemas bolsas fabricadas com estômago ou bexiga urinária (Pardal, I937, p. 47).

$\mathrm{Na}$ África Central, o instrumento utilizado era feito com uma cabaça em forma de funil, com um orifício na extremidade afilada. O líquido, previamente colocado no interior do recipiente era injetado, soprando-se na outra extremidade alargada. A superfície externa da cabaça era decorada com desenhos artísticos (Stephen-Chauvet, I936, pp. 53-54).

Entre os indígenas brasileiros também era comum o uso de purgativos e de clisteres antes da chegada dos colonizadores portugueses (Rodrigues, I934, p. 73).

$\mathrm{Na}$ medicina hipocrática o uso de purgativos e clisteres baseava-se em um conceito mais elaborado de enfermidade, qual seja o desequilíbrio dos humores.

A definição de humor (khymós, em grego) era de um constituinte básico do organismo, necessário à manutenção da vida e da saúde. Inicialmente, $o$ número de humores era indefinido; posteriormente, seu número reduziu-se a quatro: sangue, fleuma, bile amarela e bile negra, tal como se encontra no livro Da Natureza do Homem, da coleção hipocrática, livro este atribuído a Polibos, genro de Hipócrates (Hipócrates, 1932, pp. I99-207).

O estado de saúde dependeria da exata proporção e da perfeita miscigenização dos quatro humores, que poderiam alterar-se por ação de causas externas ou internas. $\mathrm{O}$ excesso ou deficiência de qualquer dos humores, assim como seu isolamento ou mistura inadequada, causariam as doenças com o seu cortejo sintomático.

A recuperação do enfermo se daria pela eliminação do humor excedente ou alterado. O médico pode auxiliar as forças curativas da natureza, retirando do corpo o "humor em excesso" ou o "humor vicioso", a fim de restaurar o equilíbrio. Com este objetivo, foram adotados os mesmos métodos terapêuticos dos egípcios: sangria, purgativos, eméticos e clisteres.

A doutrina dos quatro humores foi revitalizada por Galeno no século II d.C. Depois de Hipócrates, Galeno foi o personagem que maior influência exerceu no curso da História da Medicina. Seus ensinamentos, contidos na extensa obra que deixou escrita, foram aceitos como definitivos e intocáveis durante a Idade Média, até o Renascimento, ou seja, cerca de I 300 anos. 
Galeno não somente aceitou a doutrina da patologia humoral com os seus quatro humores, como a expandiu em seus desdobramentos relativamente à patologia e à terapêutica. A preocupação em retirar do corpo o conteúdo nocivo que estaria causando a doença, para a recuperação da saúde do enfermo, tornou-se um dogma. E, para alcançar este objetivo nada melhor do que a sangria, os purgativos, vomitórios e lavagens intestinais. Secundariamente poderiam ser usados também os revulsivos, como a ventosa, e os sudoríferos (Castiglioni, I93 I).

No período de obscurantismo da Idade Média em que a medicina se estagnou na Europa, floresceram no Oriente, entre os povos persas e árabes, importantes centros de estudos médicos como Jundi Shapur, Ispahan e Bagdá. As obras de Aristóteles, Hipócrates e Galeno, entre outras, foram traduzidas para o árabe.

O maior expoente da medicina nesse período foi Avicena, que viveu de 980 a I037 d.C. Avicena resumiu toda a ciência médica de sua época, acrescida de observações próprias, em um tratado denominado Canon da Medicina. Este tratado foi posteriormente traduzido para o latim e serviu por muito tempo como livro-texto, ao lado das obras de Hipócrates e Galeno, nos países europeus.

Avicena esposou a doutrina da patologia humoral e dos quatro humores, dedicando um capítulo sobre "O Uso dos Eliminantes: Purgação, Êmese, Ventosas, Flebotomia e Sanguessugas”. Neste capítulo, os purgativos ocupam o primeiro lugar na hierarquia dos eliminantes, como demonstra a seguinte passagem:

Quando o laxativo deixa de agir e induz o aparecimento de dores em cólica, desconforto abdominal e o paciente sente-se mal, com alterações da visão, tonturas e cefaleia, devemos recorrer aos enemas e supositórios. [...] Se o enema é ineficaz e aparecem sintomas mais graves, como rigidez, movimento dos globos oculares ou ânsia de vômito, então a sangria torna-se necessária (Avicena, I999, p. 496).

Avicena descreveu, para administração de clister, uma garrafa de couro que se comunicava com um tubo, instrumento este que também foi usado no Império Romano (Skinner, op. cit.). 
Embora mantida na Idade Média, quando as maiores preocupações deixaram de centrar-se no corpo e seu funcionamento e se deslocaram para o plano espiritual ou retornaram ao misticismo primitivo, houve um arrefecimento da teoria da autointoxicação até o século XVI. A sangria, os purgativos e as lavagens intestinais, todavia, continuaram a ser os principais recursos terapêuticos utilizados pelos médicos no tratamento das mais diversas doenças. O uso dos purgativos se justificava ainda como medida profilática, sobretudo nos casos de obstipação intestinal, em que, pelo menos teoricamente, é maior a absorção das supostas toxinas fecais. A obstipação passou a ser combatida de modo obsessivo e a ela se atribuíam os mais diversos males e sintomas decorrentes da autointoxicação, especialmente o "mau humor" das pessoas.

Os séculos XVII e XVIII foram o período de maior abuso dos purgativos, clisteres e sangrias, especialmente na França. Bouvard, primeiro médico de Luís XIII, que reinou de I610 a I643, aplicou 2 I 2 clisteres e sangrou seu real cliente 47 vezes (Dumesnil, op. cit.).

Luís XIV, que teve um reinado de 52 anos (I643-I7 I 5), bem mais longo do que o do seu antecessor, chegou a tomar purgativos, prescritos por seus médicos, cerca de duas mil vezes (Idem). Durante seu reinado, o uso de clisteres tornou-se generalizado e muitas damas chegavam a tomar mais de um clister no mesmo dia, perfumando a água com rosas, laranja, bergamota e angélica (Skinner, op. cit.).

A aplicação de clisteres, na maioria das vezes, não era função do médico e sim dos boticários, que se especializavam nessa prática e obtinham um bom rendimento com a mesma. $\mathrm{O}$ instrumento utilizado era uma seringa com capacidade para conter a quantidade desejada de líquido, o qual era injetado no reto, sob pressão, comprimindo-se o êmbolo ou pistão. Posteriormente a seringa foi substituída pelo irrigador, de metal esmaltado ou porcelana e, finalmente, pela bolsa de borracha.

Voltaire, com a sua incomparável verve, responsabilizou a "prisão de ventre" de alguns personagens famosos por importantes acontecimentos históricos, conforme se lê em seu conto "Os Ouvidos do Conde de Chesterfield e o Capelão Goudman”. Neste conto, Voltaire expõe com detalhes a fisiopatologia então aceita para explicar a autointoxicação e suas consequências.

Três filósofos, narra Voltaire, discutiam "qual o primeiro móvel de todas as ações dos homens". 
Goudman, a quem sempre lhe doera a perda de seu cargo e de sua bem-amada disse que o princípio de tudo era o amor e a ambição. Grou que vira mais terras, disse que era o dinheiro; e o grande anatomista Sidrac assegurou que era a privada.

Eis como o sábio Sidrac provou a sua tese: - Sempre observei que todos os negócios deste mundo dependem da opinião e da vontade de uma principal personagem, seja o rei, ou o primeiro-ministro, ou alto funcionário. Ora, essa opinião e essa vontade são o efeito imediato da maneira como os espíritos animais se filtram no cérebro e daí até a medula alongada; esses espíritos animais dependem da circulação do sangue; esse sangue depende da formação do quilo; esse quilo elabora-se na rede do mesentério; esse mesentério acha-se ligado aos intestinos por filamentos muito delgados; esses intestinos, se assim me é permitido dizer, estão cheios de fezes. Ora, apesar das três fortes túnicas de que cada intestino está revestido, é tudo perfurado como uma peneira; pois tudo na natureza é arejado, e não há grão de areia, por imperceptível que seja, que não tenha mais de quinhentos poros. Que acontece, então, a um homem com prisão de ventre? Os elementos mais tênues, mais delicados de suas fezes se misturam ao quilo nas veias de Asellius, vão à veia porta e ao reservatório de Pecquet; passam para a subclávia; penetram no coração do homem mais galante, da mulher mais faceira. É uma orvalhada de fezes que se lhe espalha por todo o corpo. Se esse orvalho inunda os parênquimas, os vasos e as glândulas de um atrabiliário, o seu mau humor transforma-se em ferocidade; o branco de seus olhos se torna de um sombrio ardente; seus lábios colam-se um ao outro; a cor do rosto assume tonalidades baças. Ele parece que vos ameaça; não vos aproximeis; e, se for um ministro de Estado, guardai-vos de lhe apresentar um requerimento. Informai-vos habilmente de seu criado se Sua Senhoria defecou pela manhã.

Isto é mais importante do que se julga. A prisão de ventre tem produzido às vezes, as mais sanguinolentas cenas. Meu avô, que morreu centenário, era boticário de Cromwell; contou-me muitas vezes que fazia oito dias que Cromwell não ia à privada quando mandou degolar o seu rei.

Todas as pessoas um pouco a par dos negócios do continente sabem que o duque de Guise foi várias vezes avisado de que não incomodasse Henrique III no inverno, enquanto estivesse soprando o nordeste. Em tal época, era com extrema dificuldade que o referido monarca satisfazia suas necessidades. Suas matérias lhe subiam à cabeça; era capaz, então, de todas as violências. O duque de Guise não levou a sério tão avisado conselho. Que lhe aconteceu? Seu irmão e ele foram assassinados. 
Carlos IX, seu predecessor, era o homem mais entupido do reino. Tão obstruídos estavam os condutos de seu cólon e de seu reto, que por fim o sangue lhe jorrou pelos poros. Bem se sabe que esse temperamento adusto foi uma das causas da matança de São Bartolomeu.

Pelo contrário, as pessoas que têm bom aspecto, as entranhas aveludadas, o colédoco fluente, o movimento peristáltico fácil e regular, que todas as manhãs, depois de comer, se desobrigam de uma boa evacuação, tão facilmente como os outros cospem; essas pessoas favoritas da natureza são brandas, afáveis, graciosas, benevolentes, serviçais. Um "não" na sua boca tem mais graça do que um "sim" na boca de um entupido. Tal é o domínio da privada (Voltaire, I972, pp. 595-596).

A partir do século XIX, depois de Pasteur e Koch, foram identificadas bactérias patogênicas como agentes etiológicos de muitas doenças de causa até então desconhecida. O entusiasmo pela microbiologia foi tamanho que se chegou a pensar que, se não todas, pelo menos a maior parte das enfermidades fossem produzidas por micróbios. Nesse contexto era natural que se considerasse a autointoxicação intestinal como resultante da ação de bactérias. Os resíduos alimentares que formam as fezes são um excelente meio de cultura e o cólon, um ambiente apropriado ao crescimento e colonização de numerosas espécies bacterianas, dentre as quais estariam aquelas produtoras de toxinas.

Hoje sabemos que em determinadas condições patológicas que debilitam a barreira mucosa, as bactérias podem atravessar a parede do cólon, causando peritonite espontânea e outras infecções viscerais (Rosa, Silvério, Perini et. al., 2000; Keshavarzian, 2000). Na época, entretanto, toda preocupação estava centrada na absorção das toxinas bacterianas.

A observação clínica de que, na insuficiência hepática grave, o fígado perde a sua função "desintoxicante" e manifesta-se o quadro clínico da encefalopatia hepática constituía uma evidência do acerto da teoria da autointoxicação, sobretudo porque o paciente melhora com a aplicação de lavagens intestinais.

A obstipação com a estase fecal prolongada seria um fator condicionante de maior absorção das toxinas, razão pela qual os laxantes deveriam ser usados, não somente como tratamento, mas também como medida preventiva da autointoxicação. 
Metchnikoff e seus discípulos atribuíam às bactérias anaeróbias a putrefação intestinal e consideravam o indol como a principal substância tóxica produzida no intestino. $\mathrm{O}$ indol, entretanto, resulta principalmente do metabolismo dos bacilos do grupo coliforme (Ledinghan, I9I3). Segundo Metchnikoff, a flora anaeróbia é inibida pela flora acidófila produtora de ácido lático e, nesse sentido, recomendava o uso habitual de coalhada.

No início do século xx, a doutrina da autointoxicação por estase intestinal ganhou nova dimensão, alicerçada em argumentos pseudocientíficos defendidos ou compartilhados por autores de prestígio na comunidade médica. E com uma agravante: aos purgativos e clisteres acrescentou-se o tratamento cirúrgico.

Com a descoberta dos raios-X em I 895, tornou-se possível visualizar o trato gastrointestinal em radiografias contrastadas, com o paciente de pé. Conforme ressaltou Barclay, em I936, a única anatomia a que os cirurgiões estavam habituados era a do cadáver e a dos livros-texto, em que as vísceras são representadas com o corpo em posição horizontal (Barclay, I936).

Os exames radiológicos mostravam, muitas vezes, as vísceras abdominais com localização topográfica e morfologia diferentes daquelas consideradas normais. Além disso verificou-se que a mobilidade, o diâmetro e o tempo de esvaziamento dos diversos segmentos do tubo digestivo não obedeciam ao mesmo padrão.

Como os pacientes encaminhados para exame radiológico eram sintomáticos, os sintomas por eles apresentados passaram a ser atribuídos a pretensas anormalidades. O estômago hipotônico e hipocinético, com a grande curvatura alcançando a cavidade pélvica; o cólon transverso descrevendo uma curva acentuada; o ceco móvel, o rim deslocado de sua posição anatômica, indicavam, sem dúvida, uma fixação deficiente que deveria ser corrigida pelo médico. Assim surgiram as cintas e faixas para levantar as vísceras "caídas" e as intervenções para fixação dos órgãos, as "pexias": gastropexia, colopexia, nefropexia, histeropexia.

Admitia-se que as angulações de alças, segmentos aparentemente subestenóticos, trânsito lento, ou dolicocólon, constituíam obstáculos à eliminação das fezes, propiciando a estase intestinal responsável pela autointoxicação. 
Além das "pexias", outros tipos de intervenções cirúrgicas passaram a ser praticados, tais como ressecções parciais, derivações, e até mesmo colectomia total.

Por incrível que pareça em nenhum momento se cogitou investigar se as pessoas normais, assintomáticas, apresentavam alterações semelhantes às descritas nos pacientes sintomáticos.

Foi paladino do tratamento cirúrgico para correção da estase intestinal Sir Arbuth Lane, renomado cirurgião inglês, autor do livro The Operative Treatment of Chronic Intestinal Stasis (Lane, I9 I 5 ). Segundo ele, o cólon poderia ser comparado a um reservatório ou cano de esgoto que se esvazia facilmente nos quadrúpedes. No homem, por ser bípede, o trânsito é dificultado pela gravidade, ao tracionar os pontos de fixação do intestino e produzir estrangulamentos.

O maior obstáculo ao livre trânsito das fezes, segundo Lane, estaria situado na junção retossigmoidiana, causa do alongamento e dilatação do cólon sigmoide. O ceco móvel, por sua vez, poderia eventualmente produzir angulação em relação ao íleo terminal, assim como formação de aderências. A estase ileal poderia ascender ao jejuno, ao duodeno e até ao estômago.

As consequências da estase fecal, explicava Lane, são de ordem local e sistêmica. A flora intestinal se modifica, com supercrescimento de bactérias coliformes e anaeróbias produtoras de toxinas. Com o aumento da pressão no interior do cólon, essas bactérias ascendem e proliferam no intestino delgado, duodeno e até mesmo no estômago, causando dispepsia e mau hálito.

A absorção de toxinas bacterianas debilita o organismo, em especial a camada muscular e a mucosa do estômago, resultando em ulceração gástrica, duodenal e, eventualmente, câncer gástrico. Quando em pequena quantidade, as toxinas absorvidas são eliminadas pelo fígado e pelos rins, quando em maior quantidade, entretanto, seus efeitos sistêmicos se fazem sentir.

Moynihan, outro grande cirurgião contemporâneo de Lane, assim descreve o quadro clínico da autointoxicação de maior gravidade:

Trata-se geralmente de paciente do sexo feminino de aspecto doentio, esquálida, tórax achatado, hálito acre, mãos frias e pegajosas. A pele é áspera, de cor terrosa; presença de acne e suor malcheiroso. Queixa-se de dispepsia, dor após as refeições, flatulência e obstipação rebelde. Os músculos da parede abdominal 
são flácidos e atróficos e todas as vísceras que eles devem manter suspensas estão pendentes em maior ou menor grau. Psicologicamente, é comum haver completa ausência de alegria de viver; a paciente é mal-humorada, lamurienta e, por vezes desconfiada e introspectiva (Moynihan, I9I 5).

Outras consequências maléficas foram atribuídas à autointoxicação, desde a calvície à epilepsia. Um autor relatou dois casos de epilepsia curados pela colectomia parcial.

Lane raramente se contentava com as "pexias", preferindo as operações de curto-circuito (by pass), a colectomia parcial ou a colectomia total. Os resultados pós-operatórios eram sempre bons: "os doentes ganham peso e adquirem saúde, melhorando sua qualidade de vida. À apatia e languidez sucedem a alegria de viver e o interesse pelas coisas" (Lane, op. cit.).

As operações de curto-circuito, as ressecções parciais e a colectomia total para tratamento da estase intestinal foram recebidas com entusiasmo na Europa e nos Estados Unidos e eram praticadas em centenas de hospitais, com uma mortalidade operatória de, no mínimo, I 6,5\%, verificada no Guy's Hospital de Londres (Smith, I982).

Nem todos, entretanto, estavam de acordo com a teoria da autointoxicação e com o tratamento cirúrgico da estase intestinal. Algumas vozes se levantaram contra. Hertz, em I9I3, e Einhorn, em I9I4, classificaram de absurda a teoria da autointoxicação: "Se não precisássemos do cólon, que é um órgão de considerável comprimento", dizia Einhorn, "não o possuiríamos, ou ele teria se atrofiado, o que não ocorreu" (Einhorn, I9I4, p. I I I I).

Bassler, em I9 I4, advertiu sobre a necessidade de um estudo mais aprofundado do assunto e atribuiu os bons resultados proclamados pelos cirurgiões ao efeito placebo (Bassler, I9I4).

Alvarez, em I9I9, considerou a teoria da autointoxicação um simples modismo, sem nenhuma base científica:

A moda, sob o manto da ignorância, muda como o vestuário. Diante de casos de difícil entendimento, temos sempre a tendência de recorrer a diagnósticos mal definidos, tais como "excesso de ácido úrico", "malária tifoide", "distúrbio do sistema nervoso autônomo". É o que sucede atualmente com a fantasia da autointoxicação e da infecção focal (Alvarez, r919). 
O mesmo autor demonstrou que a cefaleia e a lassidão atribuídas à autointoxicação poderiam ser produzidas colocando-se um tampão na ampola retal. A simples retirada do tampão abolia os sintomas.

Com a eclosão da Primeira Guerra Mundial (I9I4-I9I8) o interesse dos cirurgiões voltou-se para os traumatismos e ferimentos e os clínicos passaram a ocupar-se prioritariamente das disenterias, da febre tifoide e de outras doenças epidêmicas que acompanham as guerras (Smith, op. cit.).

Aos poucos, o tratamento cirúrgico da estase intestinal foi sendo abandonado. Os conceitos sobre a natureza das enfermidades foram se modificando graças ao avanço dos conhecimentos de fisiologia e patologia, com imediato reflexo na terapêutica. O uso de purgativos e clisteres, no entanto, ainda persistiu por muito tempo.

O escritor Humberto de Campos narra em seu livro de memórias que, na sua infância, era costume aplicar clisteres nas crianças enfermas e descreve sua própria experiência, relatando que ao receber um "clister de água de pimenta com outros ingredientes corria para o mato e [...] ficava a olhar com inveja os passarinhos [...] que não conheciam aqueles recursos da medicina caseira" (Campos, I939, p. 53).

$\mathrm{Na}$ segunda metade do século xx já não mais se usava a sangria e os clisteres e purgativos perderam muito de seu prestígio. Todavia, em pleno século XXI ainda perdura a crença nos benefícios advindos da limpeza intestinal como meio de evitar as doenças e preservar a saúde. O método atualmente adotado para tal fim denomina-se hidroterapia do cólon ou colonterapia e utiliza-se de moderna tecnologia por meio de aparelhos que injetam e removem automaticamente grande quantidade de água do cólon, promovendo sua limpeza. Embora sem aprovação da medicina oficial (Barrett, s.d.; Ernst, I997), é largamente usado como "medicina alternativa” em vários países, especialmente nos Estados Unidos e países europeus.

É aceito pela maioria dos especialistas em gastroenterologia e coloproctologia que a limpeza intestinal, seja por meio de purgativos, seja por lavagens, deve restringir-se a determinadas situações clínicas, como na cirrose hepática descompensada, nos casos de fecaloma, na pseudo-oclusão intestinal, ou como preparo para exame radiológico ou endoscópico do cólon, não se justificando o seu uso em indivíduos normais como meio de conservar a saúde e evitar doenças. Apesar disso, ela é utilizada em várias 
clínicas de diversos países com essa finalidade. No Brasil, por intermédio do prof. Marcus Tulio Haddad, tomamos conhecimento da existência em bairro nobre da cidade do Rio de Janeiro de uma clínica que se propõe a combater a autointoxicação decorrente da estase intestinal pela hidroterapia do cólon ou colonterapia. De um folheto dessa clínica extraímos as seguintes informações:

Como nos alimentamos em média três vezes ao dia, deveríamos evacuar de duas a três vezes ao dia, de preferência após cada refeição, devido ao reflexo gastrocólico. Como isso não acontece, pode-se acumular grande quantidade de material fecal. Assim, os detritos que deveriam ser eliminados permanecem no intestino grosso durante muito tempo gerando material tóxico que será novamente absorvido pelo organismo, produzindo uma "autointoxicação" ou toxemia. Como resultado, são desencadeados processos degenerativos que levam a desequilíbrios, envelhecimento precoce e algumas doenças.

As principais indicações da hidroterapia do cólon, constantes do mesmo folheto são: "prisão de ventre, flatulência; em processos de desintoxicação; estresse, cansaço, irritabilidade; auxiliar no tratamento da pele (acne); prevenção do câncer do intestino; enxaquecas etc.”.

Há algumas falácias nas razões alegadas para a prática da chamada colonterapia ou hidroterapia do cólon. O organismo possui mecanismos fisiológicos próprios de neutralização e eliminação de possíveis toxinas endógenas; não é função da mucosa do cólon absorver nutrientes, mas apenas água; a digestão de proteínas e a absorção de peptídios e aminoácidos se dá no intestino delgado e não no cólon; a flora bacteriana normal do cólon é necessária do ponto de vista biológico; as fezes não permanecem aderidas à mucosa em pessoas sadias.

Por outro lado, os inconvenientes da hidroterapia do cólon a considerar são o desconforto, a possiblidade de introdução de micro-organismos patogênicos, a eventual absorção excessiva de água com desequilíbrio hidroeletrolítico, e os traumatismos que podem ocorrer no reto. Os reais benefícios não foram até agora cientificamente comprovados e baseiam-se unicamente em relatos de casos, depoimentos pessoais, opinião de médicos que utilizam o processo e muita divulgação promocional. 
O importante é o funcionamento intestinal em ritmo regular, o que depende basicamente da alimentação. A obstipação deve ser corrigida, não com laxantes ou clisteres, mas com a ingestão de maior quantidade de fibras vegetais, as quais podem ser suplementadas, quando necessário, com medicamentos à base exclusivamente de fibras naturais.

\section{Referências Bibliográficas}

Alvarez, W. C. "Origin of so Called Autointoxication Symptoms". Journal of the American Medical Association, 72, pp. 8-I3, I9I9.

Avicena. The Canon of Medicine. Trad. Laleh Bakhtiar. Chicago, Great Books of the Islamic World, I999.

Barclay, A. E. “The Digestive Tract: a Radiological Study”. Londres, Cambridge Press, 1936. Apud Sмiтh, J. L. "Sir Arbuth Lane, Chronic Intestinal Stasis and Autointoxication". Annals of Internal Medicine, 96, pp. 365-369, I982.

BArrett, S. "Gastrointestinal Quackery: Colonics, Laxatives and More”. Disponível em http://www.quackwatch.org/orQuackeryRelatedTopics/gastro.html, acesso em I 8 mar. 2004 .

BASs Ler, A. "Discussion of Surgical Theories of Intestinal Stasis". Journal of the American Medical Association, 63, pp. I469-I473, I9I4.

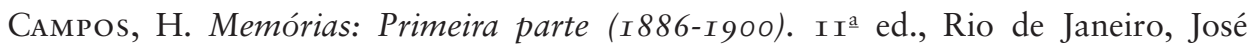
Olympio, I939.

Castiglioni, A. Histoire de la médecine. Paris, Payot, I93 I.

Dumesnil, R. Histoire illustrée de la médecine. Paris, Librairie Plon, I935.

Einhorn, M. "Intestinal Stasis". Journal of the American Medical Association, 63, p. IIII, I9I4.

ERnst, E. "Colonic Irrigation and the Theory of Autointoxication: a Triumph of Ignorance over Science”. Journal of Clinical Gastroenterology, 24 (4), pp. I96-I 98 , I997.

Heródoto. Los Nueve Libros de la Historia. $3^{\text {a }}$ ed., México, Editorial Porrúa, I98 I.

Hipócrates. "De la nature de l'homme”. Hippocrate: Oeuvres complètes, vol. II. Trad. E. Littré. Paris, Javal et Bourdeaux, I932, pp. I99-207.

Keshavarzian, A. “Alcohol: 'Ice-Breakear', Yes; 'Gut Barrier-Breaker', May Be”. The American Journal of Gastroenterology, 95, pp. I I 24-I I 25, 2000.

Lane, A. The Operative Treatment of Chronic Intestinal Stasis. Londres, James Nisbet, I9 I 5. 
Leca, A.-P. La médecine égyptienne au temps des pharaons. Paris, Editions Roger Dacosta, I97I.

Ledinghan, J. C. G. “The Bacteriological Evidence of Intestinal Intoxication”. British Medical Journal, pp. 821-823, I913.

Moynihan, B. "Intestinal Stasis”. Surgery, Gynecology \& Obstetrics, 20, pp. I 54-I 58 , I9I 5 .

Pardal, R. Medicina Aborígena Americana. Buenos Aires, Jose Anesi, I937.

Rodrigues, L. Anchieta e a Medicina. Belo Horizonte, Apollo, I934.

Rosa, H.; Silvério, A. O.; Perini, R. F. et al. "Bacterial Infection in Cirrhotic Patients and its Relationship with Alcohol”. The American Journal of Gastroenterology, 95, pp. I 290-I 293, 2000.

Saint-Hieble, C. L'instrument des apothicaires. Paris, Jean Fort, s./d..

Skinner, Henry A. The Origin of Medical Terms. $2^{\underline{a}}$ ed., Baltimore, Williams, Wilkins, I96I.

Smith, J. L. "Sir Arbuth Lane, Chronic Intestinal Stasis and Autointoxication". Annals of Internal Medicine, 96, pp. 365-369, I982.

Stephen-Chauvet. La médecine chez les peuples primitifs. Paris, Lib. Mloine, I936.

Tamayo, R .P. El Concepto de Enfermedad. México, Consejo Nacional de Ciencia y Tecnologia, I988.

Voltaire (Arouet, F. M.). Contos. São Paulo, Abril Cultural, I972. 